\title{
Predicting predatory impact of juvenile invasive lionfish (Pterois volitans) on a crustacean prey using functional response analysis: effects of temperature, habitat complexity and light regimes
}

\author{
Josie South $(\mathbb{D} \cdot$ Jaimie T. A. Dick • Monica McCard • \\ Daniel Barrios-O'Neill • Andrea Anton \\ Received: 13 December 2016 / Accepted: 19 June 2017 / Published online: 1 July 2017 \\ (C) The Author(s) 2017. This article is an open access publication
}

\begin{abstract}
The ecological implications of biotic interactions, such as predator-prey relationships, are often context-dependent. Comparative functional responses analysis can be used under different abiotic contexts to improve understanding and prediction of the ecological impact of invasive species. Pterois volitans (Lionfish) [Linnaeus 1758] is an established invasive species in the Caribbean and Gulf of Mexico, with a more recent invasion into the Mediterranean. Lionfish are generalist predators that impact a wide range of commercial and non-commercial species. Functional response analysis was employed to quantify interaction strength between lionfish and a generic prey species, the shrimp (Paleomonetes varians) [Leach 1814], under the contexts of differing temperature, habitat complexity and light wavelength. Lionfish have prey population destabilising Type II functional responses under all contexts examined. Significantly more prey were consumed at $26{ }^{\circ} \mathrm{C}$ than at $22{ }^{\circ} \mathrm{C}$. Habitat complexity did not significantly alter the functional response parameters. Significantly more prey were consumed under white light and blue light than under red light. Attack rate was significantly higher under white light than under
\end{abstract}

J. South $(\bowtie) \cdot J$. T. A. Dick · M. McCard •

D. Barrios-O’Neill

Institute for Global Food Security, School of Biological Sciences, Queen's University Belfast, MBC, Belfast BT9 7BL, UK

e-mail: josiesouth93@gmail.com

A. Anton

Red Sea Research Center, King Abdullah University of Science and Technology (KAUST), Thuwal 23955-6900, Saudi Arabia blue or red light. Light wavelength did not significantly change handling times. The impacts on prey populations through feeding rates may increase with concomitant temperature increase. As attack rates are very high at low habitat complexity this may elucidate the cause of high impact upon degraded reef ecosystems with lowdensity prey populations, although there was little protection conferred through habitat complexity. Only red light (i.e. dark) afforded any reduction in predation pressure. Management initiatives should account for these environmental factors when planning mitigation and prevention strategies.

Keywords Lionfish · Invasive species · Functional response $\cdot$ Feeding ecology

\section{Introduction}

Invasive species are a global cause for concern due to their detrimental impacts on both the economy and biodiversity (Mack et al. 2000; Pimentel et al. 2004; Simberloff 2011; Dick et al. 2013; Simberloff et al. 2013; Dick et al. 2014). Therefore, there is currently an emphasis on developing predictive methodologies that allow robust forecasting of invasion impacts (Dick et al. 2013; Simberloff et al. 2013; Caffrey et al. 2014; Dick et al. 2014). Many hypotheses and impact prediction methodologies are not pre-emptive and do not take abiotic and biotic context dependency into account (Pimm 1989; Ricciardi 2003; Kulhanek et al. 2011). This is problematic as invasions often take place across 
a range of contexts which interact to determine behaviour and therefore invasiveness and impact (Laverty et al. 2015; Paterson et al. 2015).

Recent efforts have been made to develop an impact prediction metric which can be used across contexts and takes into account the non-linear predatory response of invaders to native prey density (Alexander et al. 2012; Dick et al. 2013; Iacarella et al. 2015). This is the use of "functional responses", that is, the number of prey consumed per predator per unit of time in relation to the density of the prey (Dick et al. 2014). Solomon (1949) and Holling (1959) proposed three broad functional response types. A Type I functional response describes a linear increase in consumption of prey with prey density, whereupon handling time is negligible, however, this is regarded as specific to filter feeders (MacNeil et al. 1997; Jeschke et al. 2004). Type II functional responses are characterized by a decelerating intake rate where the consumer is limited by behavioural and/or physiological processes, with such responses potentially leading to prey extirpation due to high proportional predation at low prey densities. Type III functional responses are sigmoidal with low proportional intake rates at low prey densities (Holling 1959) and thus lead to low prey density refugia and can hence potentially stabilise prey populations. In determining the functional response type, parameter values are estimated for attack rate $(a)$, and handling time $(h)$, from which maximum feeding rate $(1 / h \mathrm{~T})$ can be estimated. By doing so, some mechanisms behind predatory impact are elucidated upon which, in turn enhances the understanding how different conditions affect predatory success. This methodology has been successful in invader impact prediction across numerous trophic groups and taxa and, furthermore, current research shows its merit in predicting impact under different abiotic and biotic contexts (Laverty et al. 2014; Alexander et al. 2015). This novel use of functional response analysis gives a unified quantification of predatory impact under multiple abiotic and biotic contexts, thus delivering a robust impact prediction technique (Dick et al. 2014; Paterson et al. 2015).

The lionfish (Pterois volitans and Pterois miles) invasion in the Caribbean and Gulf of Mexico was first reported in 1985, and more recently the presence of Pterois miles has been documented in the Mediterranean (Turan et al. 2014; Oray et al. 2015; Kletou et al. 2016). The success of this invasive marine teleost has prompted many studies on its behaviour and effects of the invasion (Kimball et al. 2004; Schofield
2010; Albins and Hixon 2011; Biggs and Olden 2011; Côté et al. 2014; Anton et al. 2016). These studies have highlighted the generalist nature of lionfish predatory feeding, indiscriminate habitat selection and diversion from their crepuscular feeding strategies (Cöté and Maljković 2010). The Caribbean and Gulf of Mexico and the Mediterranean are vulnerable systems, at risk due to anthropogenic and climate change factors (Jackson et al. 2001; Pandolfi et al. 2003), therefore the lionfish invasion poses considerable threat, not only to the biodiversity of the area but to the local fishing industries (Albins and Hixon 2011). It is thus important to investigate how resource consumption of lionfish varies within the context of current and future abiotic parameters (Englund et al. 2011; Dick et al. 2014). While there is a degree of ontogenetic prey switching; from crustaceans to fish (Morris and Akins 2009), quantification of juvenile lionfish predation rate and diet analysis is less frequently completed in sitú, compared to studies on adults (Cöté and Maljković 2010; Albins 2013; Benkwitt et al. 2013). This is due to small size making them hard to observe and gut analysis increasingly difficult due to prey size, crypsis, and difficulty in robustly surveying prey species. Juveniles have been shown to exert significant negative effect on native species abundance (Albins 2013). Further, there is emphasis on the importance of focusing on the removal of juvenile lionfish as this life stage is under represented in diver removal and has low vulnerability to predation (Barbour et al. 2011; Morris et al. 2011). Therefore, juvenile lionfish should be considered important and understudied within the context of their effect upon prey populations.

Climate change effects include rise in temperature, which may facilitate range changes through thermal acclimation. Temperature also regulates physiology, thus increasing metabolic costs (King 2005; Pörtner and Knust 2007; Gilbert et al. 2014). Furthermore, temperature increase causes degradation of coral reef complexity (Alvarez-Filip et al. 2009). Habitat complexity and presence of refuge is a mediator of predation strength and therefore a driver of community structure (McCoy and Bell 1991; Hatcher 1997; Warfe et al. 2008; Graham 2014; Rogers et al. 2014). Lionfish abundance is not correlated to rugosity (Anton et al. 2014; Bejarano et al. 2015), however, different environments may be exploited at different strengths and might affect predatory interactions (Alexander et al. 2015). Reef habitats with high structural complexity confer a large diversity of light microhabitats (Brakel 1979; Sheppard 1981; Dinesen 1983). 
High complexity habitats also provide shading from light which in turn reduces temperature and UVA/UVB exposure (Kelly and Bothwell 2002; Cocheret de la Morinière et al. 2004). Light regimes are a key modulator of activity and life events of teleost fish (Downing and Litvak 2001; Cocheret de la Morinière et al. 2004). Understanding how predatory behaviour changes with light regimes can indicate vulnerable prey species and give evidence towards potential conservation strategies (Koski et al. 2003; Fitzpatrick et al. 2013; Ranåker et al. 2014). Furthermore, it will allow an insight into understanding the impact of invasive predators at night and on mesopelagic reefs (Bassett and Montgomery 2011). Temperature, structural complexity, and light regimes are intricately linked in coral reef ecosystem dynamics. Reef ecosystems are consequently stressed by perturbations in these factors due to climatic change and alien invasions.

This study therefore aims to apply functional response analysis to determine the magnitude and form of the functional response of juvenile lionfish (Pterois volitans) on crustacean prey and whether it changes with variations in temperature regime, habitat complexity, and light regimes.

\section{Methods}

Trials were conducted in the Queen's University Belfast Marine Laboratory in Portaferry, UK in JanuaryMarch 2014 and January-March 2015. Lionfish (6$10 \mathrm{~cm}$ total length) were purchased in two batches ( $n=7, n=6$ ), from Grosvenor Tropicals, Belfast. Specimens were kept in a large tropical marine aquarium holding tank ( $\mathrm{vol}=227 \mathrm{l}$ ) at $24{ }^{\circ} \mathrm{C}$ and maintained feeding daily ad libitum on frozen anchovy. Individuals were acclimated to the holding tank for two weeks before starting trials, which typically lasted for two months. There was no significant growth during this period. Experimental tanks were 34 1 (45x30x30) tanks which were constantly aerated using a pump and air stone and maintained at $24{ }^{\circ} \mathrm{C}$. Sand was used as substrate to mimic natural conditions. Live Paleomonetes varians (Leach 1814) (Grass shrimp) were chosen as trial prey and supplied from Seahorse aquariums. This species was selected to represent a generic prey species and since juvenile lionfish predate largely on invertebrates rather than fish (Cure et al. 2012) and due to the successful use of Paleomonetes spp. (Cerino et al. 2013). Temperature treatments lasted for $24 \mathrm{~h}$. Habitat and light treatments lasted for $4 \mathrm{~h}$. Unfortunately factorial trials were not feasible at this time due to limited predator and prey supply stock.

The R package 'frair' (Pritchard 2014) was used to model the functional response type using logistic regression to determine the shape of the predator-prey interactions (proportion of prey consumed versus prey density). That is, if the proportion of prey consumed decreases with increasing prey density then the logistic regression will produce a significantly negative result and thus the functional response type can be classed as Type II, if the logistic regression produces a significantly positive result the response will be classed as Type III (Juliano 2001). Functional responses were modeled using maximum likelihood estimation (MLE; Bolker 2010) and Rogers' (1972) Random Predator Equation, due to the prey not being replaced as they were consumed:

$N_{e}=N_{o}\left(1-\exp \left(a\left(N_{e} h-T\right)\right)\right.$

where $N_{e}$ is the number of prey eaten, $N_{0}$ is the initial density of prey, $a$ is the attack rate, $h$ is the handling time and $T$ is the total time available. The Lambert $\mathrm{W}$ function was implemented to fit the model to the data (Bolker 2008). The data were non-parametrically bootstrapped ( $n=2000)$ to construct $95 \%$ confidence intervals around the mean functional response curve for each treatment. Differences in attack and handling parameters were assessed within treatments using the difference method outlined in Juliano (2001), with Bonferroni corrections when comparing between three values. Quantity of prey consumed is not included in this analysis due to prey numbers being limited by depleting prey density. All analysis was carried out in R v.3.2.2 (R Development Core Team 2015).

Temperature trials were run at $22{ }^{\circ} \mathrm{C}$ and $26^{\circ} \mathrm{C}$ to simulate the range of temperatures in which lionfish are commonly found (Kimball et al. 2004; Schofield 2009). Predators and prey were acclimated to these temperatures for $24 \mathrm{~h}$ before trial, acclimation time was longer in this instance to reduce stress due to rapid heat change. Densities of prey presented were $1,3,6,10(n=3$ per treatment). Habitat complexity trials were carried out with brown plastic pipes $(15 \times 10 \mathrm{~cm})$, which were chosen to mimic lionfish habitat of rocky ledges (e.g., lionfish could rest hanging upside down inside of the pipes), but to also provide shelter for the prey. The arenas either presented as low complexity (no pipes) or high complexity (two pipes). Fish were left to 
acclimate in the experimental trials for one hour before prey were introduced. Densities of prey presented were $1,2,3,5,7,10$ ( $n=3$ per treatment). Light trials were performed with three different light experimental treatments simulated using light emitting diodes (LEDs). The first light treatment simulated daylight in the tank using white LED lights (WL; using 42 bulbs in total), producing $4.5 \mathrm{~W}$ with a wavelength ranging from 550 to $560 \mathrm{~nm}$, (Blanco-Vives et al. 2012; Fitzpatrick et al. 2013). The second light condition was to simulate crepuscular periods using blue LED lights (BL) (38 blue LED light bulbs in total along with four white LED lights) to produce the same $4.5 \mathrm{~W}$ with a wavelength ranging from 450 to $465 \mathrm{~nm}$ (Vera et al. 2010). Red light (RL) was used to simulate complete darkness (Trippel and Neil 2003), by using a $40 \mathrm{~W}$ red spot light reflector bulb with a wavelength ranging from 620 to $630 \mathrm{~nm}$. Fish were left to acclimate in the experimental trials for one hour before prey were introduced. Densities of prey presented were $1,2,4,6,8,10,15,20,25(n=4$ per treatment).

Controls were carried out in experimental tanks containing shrimp at each prey density in each treatment, but in the absence of predatory lionfish $(n=3$ per treatment). Each fish was re-used multiple times, but experienced the density of prey only once to avoid pseudo-replication and the prey density and individual fish were chosen randomly. Fish were given at least five days between useage and were starved for three days prior to experimental procedure to standardize hunger levels.

\section{Results}

Prey survival in control groups was $>99 \%$ in all replicates, therefore any deaths in experimental groups were attributed to predation by lionfish.

Temperature effects

Logistic regression had a significantly negative first order term for $22{ }^{\circ} \mathrm{C}$ and for $26^{\circ} \mathrm{C}$, indicating Type II functional responses at both temperatures (Table 1, Fig. 1). The Type II functional response was significantly higher at $26^{\circ} \mathrm{C}$ than at $22^{\circ} \mathrm{C}$ (Table 1, Fig. 1). There was no significant difference in attack $(\mathrm{z}=0.10, p=0.91)$ and handling parameters $(\mathrm{z}=1.81, p=0.07)$ between $22{ }^{\circ} \mathrm{C}$ and $26^{\circ} \mathrm{C}$.

\section{Habitat effects}

Logistic regression had a significantly negative first order term for high and low habitat, indicating Type II functional responses for high and low habitat complexity, and the Type II functional responses did not differ significantly between habitat complexity treatments (Table 1, Fig. 2). There was no significant difference between attack $(\mathrm{z}=0.59, p=0.55)$ and handling ( $\mathrm{z}=0.61, p=0.53)$ parameters between high and low habitat complexity treatments.

\section{Light effects}

Logistic regression first order terms were significantly negative for all light treatments, indicating Type II functional responses (Table 1, Fig. 3). Type II functional responses under white and blue lights were not significantly different but the functional response under red light was significantly lower (Fig. 3). Blue light had the highest attack rate and red light the lowest attack rate (Table 1). Attack rates were significantly higher at white light than blue light $(\mathrm{z}=118,469.34, p<0.001)$ and red light $(\mathrm{z}=2.46, p<0.05)$. There was no significant difference in attack rates between blue light and red light ( $\mathrm{z}=1.26, p=0.61$ ). There were no significant differences in handling times between white and blue lights $(\mathrm{z}=2.03, p=0.12)$, white and red lights $(\mathrm{z}=1.96$, $p=0.14)$, or between blue and red lights $(\mathrm{z}=1.34$, $p=0.53)$.

\section{Discussion}

Juvenile lionfish consistently exhibited Type II functional responses across all three contexts in this study. This high proportional depletion of resources at low resource density is typical of highly damaging invasive predators (Dick et al. 2013; Dick et al. 2014; Alexander et al. 2014; Alexander et al. 2015). Our results provide a maximum feeding rate for juvenile lionfish under these abiotic contexts, giving a more realistic picture of predator-prey ecological interactions and their strengths. Juvenile lionfish are an understudied life stage in terms of individual impact upon prey populations. The conclusions from this data are limited to juveniles under experimental conditions, however, due to high lionfish fecunidity (Gardner et al. 2015) and low efficacy of juvenile removal by divers (Barbour et al. 2011; 
Table 1 First order terms and associated $p$ values, Functional Response Type, attack $(a)$ and handling $(h)$ parameter values and $p$ values and maximum feeding estimates for all treatments

\begin{tabular}{llllll}
\hline Treatment & First order term, $p$ & $\begin{array}{l}\text { Functional } \\
\text { response Type }\end{array}$ & $\begin{array}{l}\text { Attack rate } \\
(a), p\end{array}$ & $\begin{array}{l}\text { Handling time } \\
(h), p\end{array}$ & $\begin{array}{l}\text { Maximum feeding } \\
\text { estimate }\left(\mathrm{hr}{ }^{-1}\right) \\
(1 / h \mathrm{~T})\end{array}$ \\
\hline $22^{\circ} \mathrm{C}$ & $-0.180,0.06$ & II & $5.29,0.47$ & $0.28,<0.001$ & 3.6 \\
$26^{\circ} \mathrm{C}$ & $-0.223,<0.05$ & II & $4.50,0.07$ & $0.12,<0.01$ & 8.3 \\
Low complexity & $-0.308,<0.001$ & II & $14.36,0.50$ & $0.34,<0.01$ & 2.9 \\
High complexity & $-0.159,<0.05$ & II & $1.27,0.11$ & $0.26,<0.01$ & 3.8 \\
White light & $-0.153,<0.001$ & II & $6.62,<0.001$ & $0.14,<0.001$ & 7.1 \\
Blue light & $-0.147,<0.001$ & II & $41.00,<0.001$ & $0.18,<0.001$ & 5.6 \\
Red light & $-0.147,<0.001$ & II & $1.99,<0.05$ & $0.23,<0.001$ & 4.3 \\
\hline
\end{tabular}

Morris et al. 2011) they should be considered a pervasive threat to crustacean prey populations.

The attack rates between high and low temperature were similar, which suggests that handling time is the cause for increased impact under high temperatures as the lower the handling time, the higher the maximum feeding rate. This is corroborated by meta-analysis investigating temperature dependencies and scaling on the functional response, whereupon a hump shaped relationship is typical (Englund et al. 2011; Rall et al. 2012). Therefore, indicating that a variation in temperature affects physiological processes rather than behaviour (Gilbert et al. 2014). Elucidation of these novel per capita effects are important to determine, as context dependent impact assessments are lacking (Iacarella et al. 2015), and especially considering forecasting suggests that warming above the thermal optima for a species will decrease interaction strength at per capita and population level (Rall et al. 2012). Studies have determined lionfish chronic lethal minimum temperature of $10{ }^{\circ} \mathrm{C}$ and that mean winter temperatures of $14{ }^{\circ} \mathrm{C}$ and above are predictors of lionfish distribution and density (Kimball et al. 2004). Cerino et al. (2013) found that the thermal optima for lionfish feeding was $29.8^{\circ} \mathrm{C}$, and assessed previous estimations of consumption (Cöté and Maljković 2010) to be extremely high ( $>78 \%$ maximum consumption). The present study corroborates and expounds upon the high predation rates found in Cöté and Maljković (2010).
Fig. 1 Functional response curves for lionfish at $22^{\circ} \mathrm{C}$ (blue solid line) and $26^{\circ} \mathrm{C}$ (red dashed line). Shaded areas are bootstrapped $95 \%$ confidence intervals, darker shaded areas indicate overlap

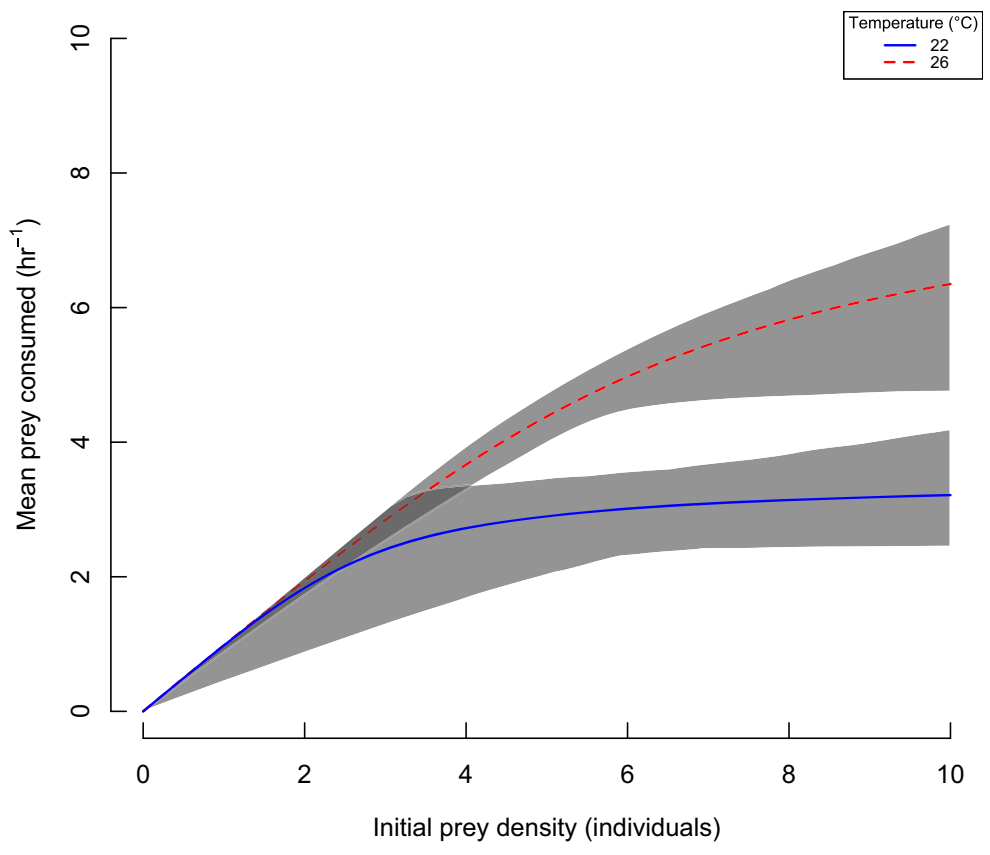


Fig. 2 Functional response curves for lionfish at low habitat complexity (red solid line) and high habitat complexity (green dashed line). Shaded areas are bootstrapped $95 \%$ confidence intervals, darker shaded areas indicate overlap

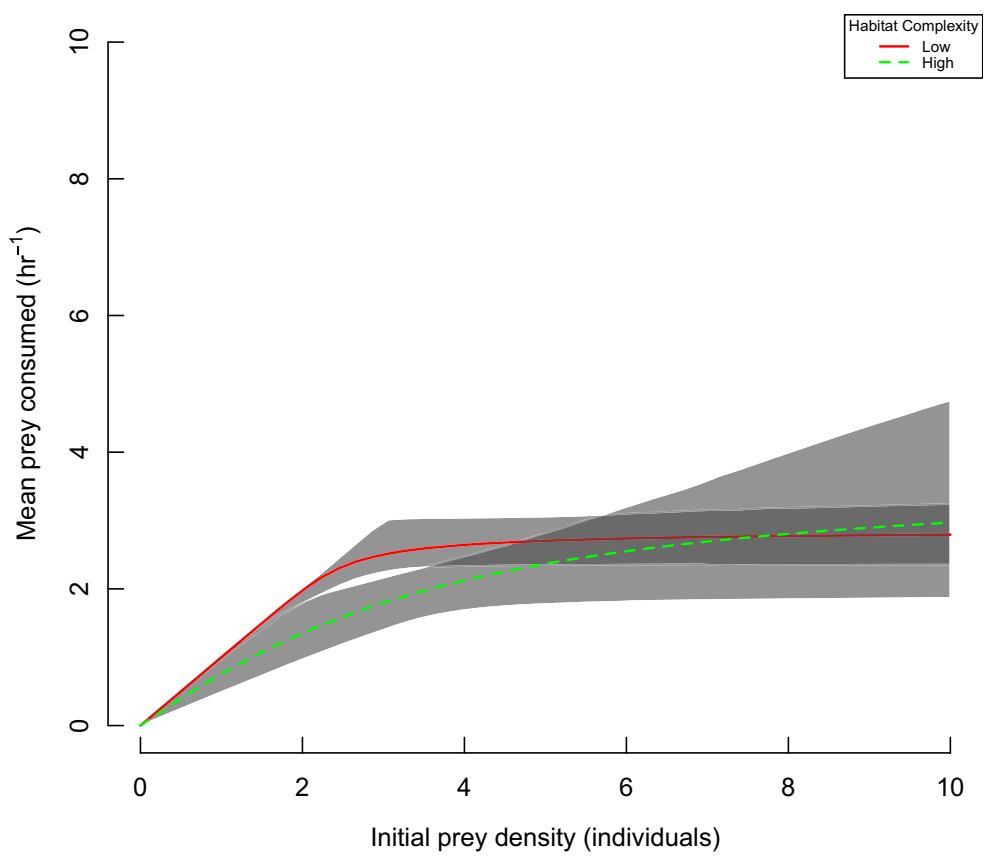

However, further temperature trials would be needed to highlight lionfish thermal optima (Iacarella et al. 2015), with relevance to functional response, i.e. proportional consumption of prey, at predicted warming temperatures in the invaded range to be able to assess potential changes in predatory behaviours with relation to rare and abundant prey populations.

Habitat complexity appears to mediate the impact of damaging alien species in a myriad of ways, as exhibited in previous studies (Barrios-O'Neill et al. 2014; Alexander et al. 2015). In our study, while both complexities revealed a Type II response; low complexity had a non-significantly higher attack rate, while high complexity had a non-significantly lower handling time. This can be attributed to habitats with a high degree of structural integrity limiting a predator's efficiency by interfering with detection of prey and the ability of the predator to catch the prey (Greene 1986; James and Heck 1994;
Fig. 3 Functional response curves for lionfish for white light (purple solid line), blue light (blue dashed line) and red light (red dotted line). Shaded areas are bootstrapped $95 \%$ confidence intervals,darker shaded areas indicate overlap

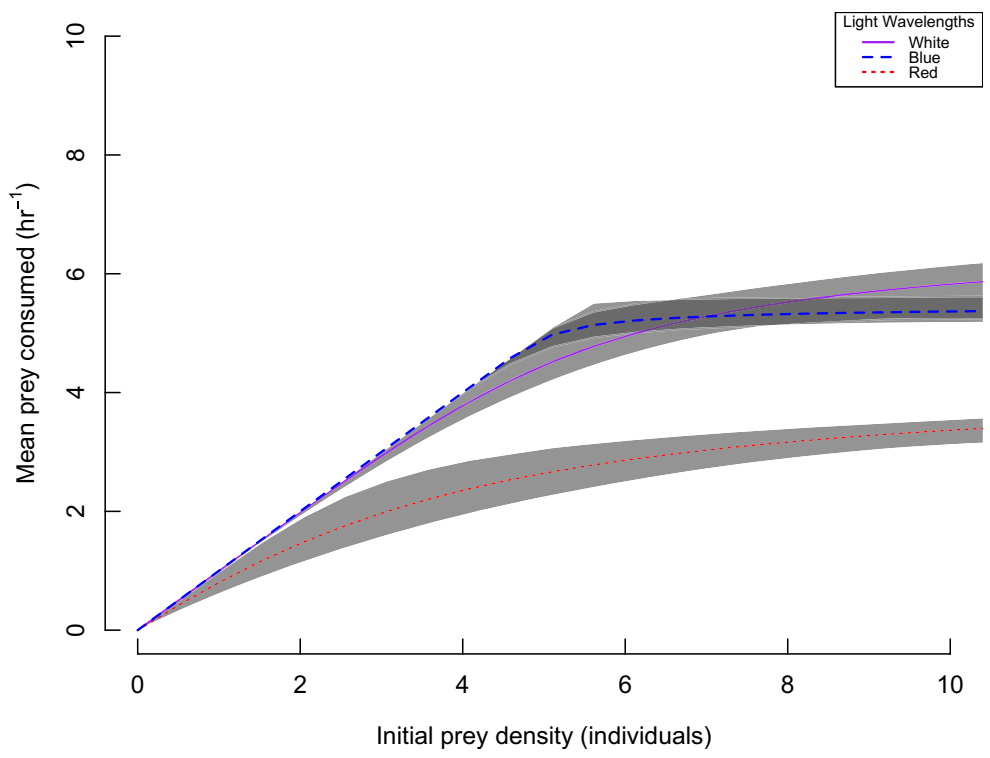


Alexander et al. 2015; Barrios-O’Neill et al. 2015). This occurs through a variety of mechanisms; the formation of a physical barrier causes disruptive implications for visual (Manatunge et al. 2000; Warfe and Barmuta 2004) and olfactory signals (Ferner et al. 2009), furthermore physical structure can provide complete or partial refuge for prey from predators (Finke and Denno 2006; Horinouchi 2007). In addition, a predator's ability to maneuver within a structure is often impaired (Winfield 1986; Bartholomew et al. 2000; Barrios-O’Neill et al. 2015). Therein, it is a general assumption that the foraging efficiency of predators ought to decrease with increasing habitat complexity (Radomski and Goeman 2001; Alexander et al. 2015), thus effectively dampening the strength of the functional response. This said, habitat complexity could work to facilitate predation (Marinelli and Coull 1987). This can occur through within refuge competition between prey (Orrock et al. 2013) and utilization of structure by predator; such as lionfish using overhanging structures for ambush predation (Biggs and Olden 2011). This may explain the shorter handling time and therefore, higher maximum feeding rate, in the higher complexity habitat despite having a lower attack rate. Habitat is thus thought of as an important mediator in predator/prey interactions (Alexander et al. 2012). While the experimental set up used in the present study could be considered limited it gives an insight into the complex ways in which habitat mediates behaviour. Further investigation of the effect of habitat complexity on predation by using fractal dimensions and predator free space (BarriosO’Neill et al. 2015) may provide further insight into the effects of structure in lionfish predation.

Light regimes are a strong modulator of animal behaviour (Schwalbe and Webb 2015). Reef fish often have strong circadian rhythms, which manifest as periods of crepuscular feeding (Helfman 1986; Domeier and Colin 1997). In the white light (daylight proxy) the fish exhibited the highest attack and lowest handling times, which translated in the highest consumption rates. The blue light proxy for crepuscular periods exhibited a steeper initial functional response incline than the other light treatments. The handling time was lowest under blue light, which supports the notion of persistent crepuscular feeding due to a decrease in predator avoidance although, none of the handling times in the light treatments differed significantly. These results differ from the predation rates calculated by Cöté and Maljković (2010), which determined that lionfish predation is more successful under overcast conditions. However, this study did not assess predation under crepuscular light conditions. There are contrasting reports on the feeding behaviour of lionfish, some suggesting all day feeding (Morris and Akins 2009; Cöté and Maljković 2010, while other evidence reports that crepuscular feeding is conserved in the invaded range (Jud and Layman 2012; Cure et al. 2012). Our results indicate that feeding will occur throughout a range of light wavelengths, albeit at significantly lower levels during dark periods. The behaviour relates to a trade off between predator visual acuity and predator avoidance by prey in low light levels (Cure et al. 2012). Individual movement and hunting behaviour was less under red light (personal observation), this reduces attack rate and increases the behaviours and processes associated with handling time. This has been noted in other species (Koski and Johnson 2002), as a reduction in swimming reduces energy costs thus allowing more to be put into growth and reproductive effort (Appelbaum and Kamler 2000); this works in the benefit of lionfish as it is a slow swimming, ambush predator (Albins and Lyons 2012). The comparative functional response was significantly lower in red light than under the white and blue light regimes; this suggests that the impact of the invasive lionfish will be lower in deep, dark water (Nuttall et al. 2014), especially when combined with the finding that the impact of the invasive lionfish is reduced in dark periods and in colder water. Our results highlight the importance of visual hunting strategies for predation success in juvenile lionfish. Further studies should pinpoint the light wavelengths at mesophotic reefs to understand the relevant impact at depth, as phase shifts to algal dominated communities have been documented on a Bahamian mesophotic coral reef in response to the lionfish invasion (Lesser and Slattery 2011), which suggests that despite the reduced impact in comparison to under other light regimes, there is still disproportionally higher resource consumption compared to native predators.

Functional response analysis has been used in this instance as a proxy for invader impact on native resources (Alexander et al. 2012; Alexander et al. 2014; Dick et al. 2014). The form of the functional response, in this case Type II, can be used to predict the measure of change the lionfish population may be exerting on prey populations (Ward et al. 2008; Jeschke et al. 2014) and therefore coral and temperate reef ecosystems. Invasive species exhibiting a Type II functional response have the capacity to drive prey populations to local extinctions if prey are unable to match predator consumption rate with 
recruitment (Sinclair et al. 1998; Twardochleb et al. 2012; Alexander et al. 2014). In this case it seems that lionfish consistently and successfully feed at a high percentage of their daily ration (Cerino et al. 2013), which thus poses a considerable threat to biodiversity and commercial fisheries. When managing damaging invaders, after pinpointing what species are most at risk, it is essential to identify the interplay between biotic and abiotic factors and how the environment mediates predator-prey interaction strengths. While the present study is not factorial, it highlights variables that have the capacity to mediate predation impact. The main mechanism identified here revolves around the ability of lionfish to locate prey rather than handling limitations. However, temperature remains a pervasive driver for invasion success by mediating handling times and thus maximum feeding rates through physiological mechanisms. It should be considered that handling time is made up of a concert of both behavioural and physiological processes (Holling 1968; Hassell 1978) and can be overestimated due to the combination of processes within one parameter, as in this model (Dell et al. 2011; Sentis et al. 2013).

Nonetheless, due to the high exploitation of low prey densities by lionfish at all life stages, management should focus on the conservation of rare species by moderation of other pressures such as fishing and habitat destruction while developing further methods to remove juvenile lionfish from reefs. Currently, prevention of marine invasions is becoming increasingly futile due to connectivity and other human mediated changes in the abiotic environment, therefore it is important to develop the predictive capacity of novel uses of functional response analysis in cohesion with other trait based methodologies so as to combat the invasive impact of alien species (Parker et al. 1999; MacNeil et al. 2013; Dick et al. 2014).

Acknowledgements We thank G. Riddell, E. Gorman and B. McNamara for their technical support and assistance with animal maintenance, and J. Sigwart for her help in stimulating discussion. We thank anonymous peer reviewers for their helpful suggestions. This research was funded by the Department of Agriculture, Environment and Rural Affairs (Northern Ireland).

\section{Compliance with ethical standards}

Ethics statement All applicable international, national and/or institutional guidelines for the care and use of animals were followed.
Open Access This article is distributed under the terms of the Creative Commons Attribution 4.0 International License (http:// creativecommons.org/licenses/by/4.0/), which permits unrestricted use, distribution, and reproduction in any medium, provided you give appropriate credit to the original author(s) and the source, provide a link to the Creative Commons license, and indicate if changes were made.

\section{References}

Albins MA (2013) Effects of invasive Pacific red lionfish Pterois volitans versus a native predator on Bahamian coral-reef fish communities. Biol Invasions 15(1):29-43. doi:10.1007 /s10530-012-0266-1

Albins MA, Hixon MA (2011) Worst case scenario: potential long term effects of invasive predatory lionfish (Pterois volitans) on Atlantic and Carribean coral reef communities. Environ Biol Fish 96:1151. doi:10.1007/s10641-011-9795-Z

Albins MA, Lyons PJ (2012) Invasive red lionfish Pterois volitans blow directed jets of water at prey fish. Mar Ecol Prog Ser 448:1-5

Alexander ME, Dick JTA, O'Connor N, Haddaway NR, Farnsworth K (2012) Functional responses of the intertidal amphipod Echinogammarus Marinus: effects of prey supply, model selection and habitat complexity. Mar Ecol Prog Ser. doi:10.3354/meps09978

Alexander ME, Dick JTA, Weyl OLF, Robinson TB, Richardson DM (2014) Existing and emerging high impact invasive species are characterized by higher functional responses than natives. Biol Lett 10:20130946. doi:10.1098/rsbl.2013.0946

Alexander ME, Kaiser H, Weyl OLF, Dick JTA (2015) Habitat simplification increases the impact of a freshwater invasive fish. Environ Biol Fish 98(2):477-486. doi:10.1007/s10641014-0278-Z

Alvarez-Filip L, Dulvy NK, Gill JA, Côté IM, Watkinson AR (2009) Flattening of Caribbean coral reefs : region-wide declines in architectural complexity. Proc R Soc Biol 276: 3019-3025

Anton A, Simpson MS, Vu I (2014) Environmental and biotic correlates to lionfish invasion success in Bahamian coral reefs. PLoS One 9(9):e106229. doi:10.1371/journal. pone. 0106229

Anton A, Cure K, Layman C, Puntila R, Simpson M, Bruno J (2016) Prey naiveté to invasive lionfish Pterois volitans on Caribbean coral reefs. Mar Ecol Prog Ser 544:257-269. doi:10.3354/meps 11553

Appelbaum S, Kamler E (2000) Survival, growth, metabolism and behavior of Clarias gariepinus (Burchell) early stages under different light conditions. Aquac Eng 22:269-287

Barbour AB, Allen MS, Frazer TK, Sherman KD, Blackwell P (2011) Evaluating the potential efficacy of invasive lionfish (Pterois volitans) removals. PLoS One 6(5):e19666. doi:10.1371/journal.pone.0019666

Barrios-O'Neill D, Dick JTA, Ricciardi A, Macisaac HJ, Emmerson MC (2014) Deep impact: in situ functional responses reveal context-dependent interactions between vertically migrating invasive and native mesopredators and shared 
prey. Freshw Biol 59(10):2194-2203. doi:10.1111 /fwb.12423

Barrios-O'Neill D, Dick JTA, Emmerson MC, Ricciardi A, MacIsaac HJ (2015) Predator-free space, functional responses and biological invasions. Funct Ecol 29(3):377384. doi:10.1111/1365-2435.12347

Bartholomew A, Diaz R, Cicchetti G (2000) New dimensionless indices of structural habitat complexity: predicted and actual effects on a predator's foraging success. Mar Ecol Prog Ser. doi:10.3354/meps206045

Bassett DK, Montgomery JC (2011) Investigating nocturnal fish populations in situ using baited underwater video: with special reference to their olfactory capabilities. J Exp Mar Biol Ecol 409(1-2):194-199. doi:10.1016/j.jembe.2011.08.019

Bejarano S, Lohr K, Hamilton S, Manfrino C (2015) Relationships of invasive lionfish with topographic complexity, groupers and native prey fishes in little Cayman. Mar Biol 162:253. doi:10.1007/s00227-014-2595-3

Benkwitt CE, Beets J, Schmitt R, Holbrook S, Chesson P (2013) Density-dependent growth in invasive lionfish (Pterois volitans). PLoS One 8(6):e66995. doi:10.1371/journal. pone.0066995

Biggs CR, Olden JD (2011) Multi-scale habitat occupancy of invasive lionfish (Pterois volitans) in coral reef environments of Roatan, Honduras. Aquat Invasions 6(3):347-353. doi:10.3391/ai.2011.6.3.11

Blanco-Vives B, Aliaga-Guerrero M, Cañavate JP, García-Mateos G, Martín-Robles AJ, Herrera-Pérez P, Muñoz-Cueto JA, Sánchez-Vázquez FJ (2012) Metamorphosis induces a light-dependent switch in Senegalese sole (Solea senegalensis) from diurnal to nocturnal behavior. J Biol Rhythm 27(2):135-144. doi:10.1177/0748730411435303

Bolker BM (2008) Emdbook: ecological models and data in R. Princeton University Press, Princeton

Bolker BM (2010) bbmle: tools for general maximum likelihood estimation. R Package. http://www.cran.rproject.org/

Brakel WH (1979) Small scale spatial variation in light available to coral reef benthos: quantum irradiance measurements from a Jamaican reef. Bull Mar Sci 29(3):406-413

Caffrey JM, Baars JR, Barbour JH, Boets P, Boon P, Davenport K, Dick JTA, Early J, Edsman L, Gallagher C, Gross J, Heinimaa P, Horrill C, Hudin S, Hulme PE, Hynes S, MacIsaac HJ, McLoone P, Millane M, Moen TL, Moore N, Newman J, O'Conchuir R, O'Farrell M, O'Flynn C, Oidtmann B, Renals T, Ricciardi A, Roy H, Shaw R, van Valkenburg JLCH, Weyl O, Williams F, Lucy FE (2014) Tackling invasive alien species in Europe: the top 20 issues. Management of Biological Invasions 5:1-20

Cerino D, Overton AS, Rice JA, Morris JA (2013) Bioenergetics and trophic impacts of the invasive Indo-Pacific lionfish. Trans Am Fish Soc 142:1522-1534. doi:10.1080 /00028487.2013.811098

Cocheret de la Morinière E, Nagelkerken I, van der Meij H, van der Velde G (2004) What attracts juvenile coral reef fish to mangroves: habitat complexity or shade? Mar Biol 144(1): 139-145. doi:10.1007/s00227-003-1167-8

Cöté IM, Maljković A (2010) Predation rates of Indo-Pacific lionfish on Bahamian coral reefs. (2010). Mar Ecol Prog Ser 404:219-225. doi:10.3354/meps08458

Côté IM, Akins L, Underwood E, Curtis-Quick J, Green SJ (2014) Setting the record straight on invasive lionfish control: culling works. Peer J PrePrints, 2Côté, I. e398v1. doi:10.7287/peerj.preprints.398v1

Cure K, Benkwitt CE, Kindinger TL, Pickering EA, Pusack TJ, McIlwain JL, Hixon MA (2012) Comparative behavior of red lionfish Pterois volitans on native Pacific versus invaded Atlantic coral reefs. Mar Ecol Prog Ser 467:181-192

Dell AI, Pawar S, Savage VM (2011) Systematic variation in the temperature dependence of physiological and ecological traits. Proc Natl Acad Sci 108(26):10591-10596. doi:10.1073/pnas.1015178108

Dick JTA, Gallagher K, Avlijas S, Clarke HC, Lewis SE, Leung S, Minchin D, Caffrey J, Alexander ME, Maguire C, Harrod C, Reid N, Haddaway NR, Farnsworth KD, Penk M, Ricciardi A (2013) Ecological impacts of an invasive predator explained and predicted by comparative functional responses. Biol Invasions 15:837-846

Dick JTA, Alexander ME, Jeschke JM, Ricciardi A, MacIsaac HJ, Robinson TB et al (2014) Advancing impact prediction and hypothesis testing in invasion ecology using a comparative functional response approach. Biol Invasions 16:735-753

Dinesen ZD (1983) Patterns in the distribution of soft corals across the central great barrier reef. Coral Reefs 1:229-236

Domeier ML, Colin PL (1997) Tropical reef fish spawning Aggregrations: defined and reviewed. Bull Mar Sci 60(3): 698-726

Downing G, Litvak MK (2001) The effect of light intensity and spectrum on the incidence of first feeding by larval haddock. J Fish Biol 59(6):1566-1578. doi:10.1111/j.1095-8649.2001. tb00221.x

Englund G, Ohlund G, Hein CL, Diehl S (2011) Temperature dependence of the functional response. Ecol Lett 14(9): 914-921. doi:10.1111/j.1461-0248.2011.01661.x

Ferner M, Smee D, Weissburg M (2009) Habitat complexity alters lethal and non-lethal olfactory interactions between predators and prey. Mar Ecol Prog Ser. doi:10.3354/meps07764

Finke DL, Denno RF (2006) Spatial refuge from intraguild predation: implications for prey suppression and trophic cascades. Oecologia 149(2):265-275. doi:10.1007/s00442-006-0443-y

Fitzpatrick C, McLean D, Harvey ES (2013) Using artificial illumination to survey nocturnal reef fish. Fish Res 146:4150. doi:10.1016/j.fishres.2013.03.016

Gardner PG, Frazer TK, Jacoby CA, Yanong RPE (2015) Reproductive biology of invasive lionfish (Pterois spp.) Front Mar Sci 2:1-10. doi:10.3389/fmars.2015.00007

Gilbert B, Tunney TD, McCann KS, DeLong JP, Vasseur DA, Savage V, Shurin JB, Dell AI, Barton BT, Harley CDG, Kharouba HM, Kratina P, Blanchard JL, Clements C, Winder M, Greig HS, O'Connor MI (2014) A bioenergetic framework for the temperature dependence of trophic interactions. Ecol Lett 17(8):902-914. doi:10.1111/ele.12307

Graham NAJ (2014) Habitat complexity: coral structural loss leads to fisheries declines. Curr Biol 24(9):359-361. doi:10.1016/j. cub.2014.03.069

Greene CH (1986) Patterns of prey selection: implications of predator foraging tactics. Am Nat 128:824-839

Hassell MP (1978) Functional responses. In: Hassell MP (ed) The dynamics of arthropod predator-prey systems. Princeton University Press, Princeton, pp 28-49

Hatcher BG (1997) Coral reef ecosystems: how much greater is the whole than the sum of the parts? Coral Reefs 16(0):S77S91. doi:10.1007/s003380050244 
Helfman GS (1986) Fish behaviour by day, night and twilight. In: The behaviour of teleost fishes. Springer US, Boston, pp 366-387. doi:10.1007/978-1-4684-8261-4 14

Holling CS (1959) Some characteristics of simple types of predation and parasitism. Can Entomol 91:385-398

Holling CS (1968) The tactics of a predator. In "Insect Abundance". Symp R Entomol Soc London 4, pp 47-58

Horinouchi M (2007) Review of the effects of within-patch scale structural complexity on seagrass fishes. J Exp Mar Biol Ecol 350(1):111-129. doi:10.1016/j.jembe.2007.06.015

Iacarella JC, Dick JTA, Alexander ME, Ricciardi A (2015) Ecological impacts of invasive alien species along temperature gradients: testing the role of environmental matching. Ecol Appl 25(3):706-716. doi:10.1890/14-0545.1

Jackson JBC, Kirby MX, Berger WH, Bjorndal KA, Botsford LW, Bourque BJ, Bradbury RH, Cooke R, Erlandson J, Estes JA, Hughes TP, Kidwell S, Lange CB, Lenihan HS, Pandolfi JM, Peterson CH, Steneck RS, Tegner MJ, Warner RR (2001) Historical overfishing and the recent collapse of coastal ecosystems. Science 293:629-638

James PL, Heck KL (1994) The effects of habitat complexity and light intensity on ambush predation within a simulated seagrass habitat. J Exp Mar Biol Ecol 176(2):187-200. doi:10.1016/0022-0981(94)90184-8

Jeschke JM, Kopp M, Tollrian R (2004) Consumer-food systems: why type I functional responses are exclusive to filter feeders. Biol Rev Camb Philos Soc 79(2):337-349 Retrieved from http://www.ncbi.nlm.nih.gov/pubmed/15191227

Jeschke JM, Bacher S, Blackburn TM, Dick JTA, Essl F, Evans T, Gaertner M, Hulme PE, Kühn I, Mrugała A, Pergl J, Pyšek P, Rabitsch W, Ricciardi A, Richardson DM, Sendek A, Vilà M, Winter M, Kumschick S (2014) Defining the impact of nonnative species. Conserv Biol 28:1188-1194. doi:10.1111 /cobi.12299

Jud ZR, Layman CA (2012) Site fidelity and movement patterns of invasive lionfish, Pterois spp., in a Florida estuary. J Exp Mar Biol Ecol 414-415:69-74

Juliano SA (2001) Nonlinear curve fitting: predation and functional response curves. In: Scheiner SM, Gurevitch J (eds) Design and analysis of ecological experiments. Oxford University Press, Oxford, pp 178-196

Kelly DJ, Bothwell ML (2002) Avoidance of solar ultraviolet radiation by juvenile coho salmon ( Oncorhynchus kisutch ). Can J Fish Aquat Sci 59(3):474-482. doi:10.1139/f02-023

Kimball ME, Miller JM, Whitfield PE, Hare JA (2004) Thermal tolerance and potential distribution of invasive lionfish (Pterois volitans/miles complex) on the east coast of the United States. Mar Ecol Prog Ser 283:269-278

King JR (2005) Report of the study group on fisheries and ecosystem responses to recent regime shifts. PICES Scientific Report 28:162

Kletou D, Hall-Spencer JM, Kleitou P (2016) A lionfish (Pterois miles) invasion has begun in the Mediterranean Sea. Marine Biodiversity Records 9(1):46. doi:10.1186/s41200-0160065-y

Koski ML, Johnson BM (2002) Functional response of kokanee salmon (Oncorhynchus nerka) to daphnia at different light levels. Can J Fish Aquat Sci 59:707-716. doi:10.1139/F02-045

Koski ML, Johnson BM, Stecklein TM (2003) Effects of light on size-selectivity of kokanee feeding on daphnia. J Fish Biol 62(6):1456-1461. doi:10.1046/j.1095-8649.2003.00121.x
Kulhanek SA, Ricciardi A, Leung B (2011) Is invasion history a useful tool for predicting the impacts of the world's worst aquatic invasive species? Ecol Appl 21(1):189-202. doi:10.1890/09-1452.1

Laverty C, Dick JTA, Alexander ME, Lucy FE (2014) Differential ecological impacts of invader and native predatory freshwater amphipods under environmental change are revealed by comparative functional responses. Biol Invasions. doi:10.1007/s10530-014-0832-9

Laverty C, Dick JTA, Alexander ME, Lucy FE (2015) Differential ecological impacts of invader and native predatory freshwater amphipods under environmental change are revealed by comparative functional responses. Biol Invasions 17:1761-1770

Lesser MP, Slattery M (2011) Phase shift to algal dominated communities at mesophotic depths associated with lionfish (Pterois volitans) invasion on a Bahamian coral reef. Biol Invasions 13:1855-1868

Mack RN, Simberloff D, Lonsdale WM, Evans H, Clout M, Bazzaz FA (2000) Issues in ecology. Bull Ecol Soc Am 86(4):249-250. doi:10.1890/0012-9623(2005)86[249 b:IIE]2.0.CO;2

MacNeil C, Dick JTA, Elwood RW (1997) The trophic ecology of freshwater gammarus spp. (Crustacea: Amphipoda): problems and perspectives concerning the functional feeding group concept. Biol Rev Camb Philos Soc 72(3):349-364

MacNeil C, Dick JTA, Alexander ME, Dodd JA, Ricciardi A (2013) Predators vs. alien: differential biotic resistance to an invasive species by two resident predators. NeoBiota 19:119. doi:10.3897/neobiota

Manatunge J, Asaeda T, Priyadarshana T (2000) The influence of structural complexity on fish-zooplankton interactions: a study using artificial submerged macrophytes. Environ Biol Fish 58:425-438

Marinelli RL, Coull BC (1987) Structural complexity and juvenile fish predation on meiobenthos: an experimental approach. $\mathrm{J}$ Exp Mar Biol Ecol 108(1):67-81. doi:10.1016/0022-0981 (87)90131-6

McCoy ED, Bell SS (1991) Habitat structure: the evolution and diversification of a complex topic. In: Bell, SS et al (eds), Habitat structure: the physical arrangement of objects in space. Chapman and Hall, pp. 3-27

Morris JA, Akins JL Jr (2009) Feeding ecology of the invasive lionfish (Pterois volitans) in the Bahamian archipelago. Envrion Biol Fishes 86:389-398

Morris JA, Shertzer KW, Rice JA (2011) A stage-based matrix population model of invasive lionfish with implications for control. Biol Invasions 13(1):7-12. doi:10.1007/s10530010-9786-8

Nuttall MF, Johnston MA, Eckert RJ, Embesi JA, Hickerson EL, Schmahl GP (2014) Lionfish (Pterois volitans [Linnaeus, 1758] and $P$. miles [Bennett, 1828]) records within mesophotic depth ranges on natural banks in the northwestern Gulf of Mexico. BioInvasions Records 3(2):111-115. doi:10.3391/bir.2014.3.2.09

Oray IK, Sinay E, Saadet Karakulak F, Yildız T (2015) An expected marine alien fish caught at the coast of northern Cyprus: Pterois miles (Bennett, 1828). Journal of Applied Icthyology 31:733-735. doi:10.1111/jai.12857

Orrock JL, Preisser EL, Grabowski JH, Trussell GC (2013) The cost of safety: refuges increase the impact of predation risk in 
aquatic systems. Ecology 94(3):573-579. doi:10.1890/120502.1

Pandolfi JM, Bradbury RH, Sala E, Hughes TP, Bjorndal KA, Cooke RG, McArdle D, McClenachan L, Newman MJH, Paredes G, Warner RR, Jackson JBC (2003) Global trajectories of the long-term decline of coral reef ecosystems. Science 301(5635):955-958

Parker IM, Simberloff D, Lonsdale WM, Goodell K, Wonham M, Kareiva PM, Williamson MH, Von Holle B, Moyle PB, Byers JE, Goldwasser L (1999) Impact: toward a framework for understanding the ecological effects of invaders. Biol Invasions 1(1):3-19. doi:10.1023/A:1010034312781

Paterson RA, Dick JTA, Pritchard DW, Ennis M, Hatcher MJ, Dunn AM (2015) Predicting invasive species impacts: a community module functional response approach reveals context dependencies. J Anim Ecol 84(2):453-463. doi:10.1111/1365-2656.12292

Pimentel D, Zuniga R, Morrison D (2004) Update on the environmental and economic costs associated with alien-invasive species in the United States. Ecol Econ 52:237-288. doi:10.1016/j.ecolecon.2004.10.002

Pimm SL (1989) Theories of predicting success and impact of introduced species. In: Biological invasions: a global perspective, Drake JA et al. (Eds) John Wiley and Sons, New York, pp 351-67

Pörtner HO, Knust R (2007) Climate change affects marine fishes through the oxygen limitation of thermal tolerance. Science (New York, N.Y.) 315(5808):95-97. doi:10.1126 /science.1135471

Pritchard DW (2014) Frair: a package for functional response analysis in $\mathrm{R}$

R Development Core Team (2015) R: A Language and Environment for Statistical Computing. R Foun- dation for Statistical Computing, Vienna, Austria. ISBN 3-900051-070, URL http://www.R-project.org

Radomski P, Goeman TJ (2001) Consequences of human lakeshore development on emergent and floating-leaf vegetation abundance. North Am J Fish Manag 21:46-61

Rall BC, Brose U, Hartvig M, Kalinkat G, Schwarzmüller F, Vucic-Pestic O, Petchey OL (2012) Universal temperature and body-mass scaling of feeding rates. Philos Trans R SocLond. Series B Biol Sci 367(1605):2923-2934. doi:10.1098/rstb.2012.0242

Ranåker L, Persson J, Jönsson M, Nilsson PA, Brönmark C (2014) Piscivore-prey fish interactions: mechanisms behind diurnal patterns in prey selectivity in brown and clear water. PLoS One 9(11):e102002. doi:10.1371/journal.pone.0102002

Ricciardi A (2003) Predicting the impacts of an introduced species from its invasion history: an empirical approach applied to zebra mussel invasions. Freshw Biol 48(6):972-981. doi:10.1046/j.1365-2427.2003.01071.x

Rogers D (1972) Random search and insect population models. J Anim Ecol 41:369-383

Rogers A, Blanchard JL, Mumby PJ (2014) Vulnerability of coral reef fisheries to a loss of structural complexity. Curr Biol 5;24(9):1000-1005

Schofield PJ (2009) Geographic extent and chronology of the invasion of non- native lionfish (Pterois volitans [Linnaeus 1758] and P. miles [Bennett 1828]) in the western North Atlantic and Caribbean Sea. Aquatic. Invasions 4:473-479
Schofield PJ (2010) Update on geographic spread of invasive Lionfishes (Pterois volitans [Linnaeus, 1758] and P. miles [Bennett, 1828]) in the western North Atlantic Ocean, Caribbean Sea and Gulf of Mexico. Aquat Invasions 5(Supplement 1):117-122

Schwalbe MAB, Webb JF (2015) The effect of light intensity on prey detection behavior in two Lake Malawi cichlids, Aulonocara stuartgranti and Tramitichromis sp. J Comp Physiol A Neuroethol Sens Neural Behav Physiol 201(4): 341-356. doi:10.1007/s00359-015-0982-y

Sentis A, Hemptinne J-L, Brodeur J (2013) Parsing handling time into its components: implications for responses to a temperature gradient. Ecology 94(8):1675-1680. doi:10.1890/122107.1

Sheppard CRC (1981) Illumination and the coral community beneath tabular Acropora ispecies. Mar Biol 64:53-58

Simberloff D (2011) How common are invasion-induced ecosystem impacts? Biol Invasions 13:1255-1268

Simberloff D, Martin JL, Genovesi P, Maris V, Wardle DA, Aronson $J$ et al (2013) Impacts of biological invasions: what's what and the way forward. Trends Ecol Evol 28:5866

Sinclair ARE, Pech RP, Dickman CR, Hik D, Mahon P, Newsome AE (1998) Predicting effects of predation on conservation of endangered prey. Conserv Biol 12:564-575

Solomon ME (1949) The natural control of animal populations. J Anim Ecol 18:1-35

Trippel EA, Neil SR (2003) Effects of photoperiod and light intensity on growth and activity of juvenile haddock (Melanogrammus aeglefinus). Aquaculture 217(1-4):633645. doi:10.1016/S0044-8486(02)00198-9

Turan C, Ergüden D, Gürlek M, Yağlığlu D, Uyan A, Uygur N (2014) First record of the Indo-Pacific lionfish Pterois miles (Bennett, 1828) (Osteichthyes: Scorpaenidae) for the Turkish marine waters. J Black Sea / Mediterr Environ 20(2):158163

Twardochleb LA, Novak M, Moore JW (2012) Using the functional response of a consumer to predict biotic resistance to invasive prey. Ecol Appl 22:1162-1171

Vera LM, Davie A, Taylor JF, Migaud H (2010) Differential light intensity and spectral sensitivities of Atlantic salmon, European sea bass and Atlantic cod pineal glands ex vivo. Gen Comp Endocrinol 165(1):25-33. doi:10.1016/j. ygcen.2009.05.021

Ward DM, Nislow KH, Folt CL (2008) Predators reverse the direction of density dependence for juvenile salmon mortality. Oecologia 156:515-522

Warfe DM, Barmuta LA (2004) Habitat structural complexity mediates the foraging success of multiple predator species. Oecologia 141:171-178

Warfe DM, Barmuta LA, Wotherspoon S (2008) Quantifying habitat structure: surface convolution and living space for species in complex environments. Oikos 117(12):17641773. doi:10.1111/j.1600-0706.2008.16836.x

Winfield IJ (1986) The influence of simulated aquatic macrophytes on the zooplankton consumption rate of juvenile roach, Rutilus rutilus, rudd, Scardinius erythrophthalmus, and perch, Perca fluviatilis. Journal of Fish Biology 29(sa): 37-48. doi:10.1111/j.1095-8649.1986.tb04997.x 